\title{
Granulomatous Mastitis: A Rare Cause of Male Breast Lump
}

\author{
Abdel Rahman A. Al Manasra Mohammad F. Al-Hurani \\ Department of General Surgery and Urology, Faculty of Medicine, Jordan University of \\ Science and Technology, Irbid, Jordan
}

\section{Keywords}

Granulomatous mastitis - Male breast

\begin{abstract}
Background: Mastitis is a common benign disorder of the female breast. It is frequently associated with tenderness, swelling and nipple discharge. We are describing an extremely rare case of an idiopathic granulomatous mastitis in the male breast. Only 1 previous case was reported. Case Report: A 29-year-old male patient presented with a hard, painless lump in the right breast of 2 weeks duration. The patient underwent surgical excision with margin. The histopathologic findings were consistent with granulomatous mastitis. The case was reported as idiopathic granulomatous mastitis after exclusion of all known causes of the disease. Conclusion: Granulomatous mastitis is rare in females and extremely rare in male breast tissue. Since this disease mimics breast cancer in its clinical picture and radiologic findings are usually not conclusive, surgical excision is recommended in all cases.
\end{abstract}

(C) 2016 The Author(s)

Published by S. Karger AG, Basel

\section{Introduction}

Multiple experimental and clinical studies demonstrate a similar origin and development of hyperplastic and inflammatory processes in breast tissue of both men and women [1]. The term mastitis has been used to describe infectious and aseptic breast tissue inflam- 
mation. Granulomatous mastitis (GM) is a chronic form of the inflammatory disorder of the breast. Its importance emerges from the fact that it mimics breast cancer clinically and radiologically, especially in elderly patients, and the definite diagnosis cannot be reached without histological examination [2]. Idiopathic GM (IGM) is a rare disorder in females and exceptionally rare in male patients; there is only 1 reported case of IGM in males.

\section{Case Presentation}

We report the case of a 29-year-old male patient (smoker) not known to have any medical illnesses. He presented to our outpatient clinic at King Abdullah University Hospital, Jordan, complaining of a painless mass in the right breast of 2 weeks duration. The patient denied any history of trauma. The systemic review and family history were unremarkable. The examination revealed a retroareolar painless lump in the right breast at 2 o'clock, about $1 \times$ $1 \mathrm{~cm}$ in diameter, not associated with skin changes or regional lymphadenopathy. Contralateral breast and axillary lymph nodes were unremarkable.

Breast ultrasound showed a hypoechoic soft tissue lesion measuring about $5 \times 2 \mathrm{~mm}$ with increased vascularity. Laboratory tests including complete blood count and blood chemistry were within normal ranges.

An excisional biopsy with margin through a periareolar skin incision was performed. Histopathology revealed a $1.3 \times 1 \times 0.4$-cm mass, with clusters of inflammatory cells including lymphocytes, neutrophils, epithelioid histiocytes and giant cells surrounding a cyst-like lesion lined by squamous cells, consistent with GM (fig. 1).

The tissue was cultured, and special stains were used. No microorganisms were identified. There was no evidence of malignancy. Patient follow-up at 3 months did not show any evidence of recurrence.

\section{Discussion}

Benign lesions of the male breast are uncommon. These include nipple adenoma, duct ectasia and cystic hyperplasia. Gynecomastia is still the most encountered abnormality in male breasts, with a reported prevalence of approximately $4 \%$ in the age group of 10-19 years [3]. Mastitis, a benign breast inflammation, is exceedingly rare in males with only few cases reported in the literature so far.

IGM has first been described in females in 1972 by Kessler and Wolloch [4]. Over the last 3 decades, about 200 cases were reported [5]. The incidence of IGM in males is extremely rare. The only reported case dates back to 2005, by Reddy et al. [6]. The diagnosis of IGM was established in a 46-year-old male who presented with a subareolar breast lump. Microscopic examination of the excised lesion revealed multiple epithelioid and multinucleated giant cells in a background of chronic granulomatous inflammation [6].

IGM is characterized by chronic, noncaseating granulomatous lobulitis $[7,8]$. There is no clear etiology for the disease; possible causes include autoimmune response to secretions from traumatized ducts $[9,10]$, infections [11-14], hyperprolactinemia [15], diabetes mellitus, smoking and lack of alpha-1 antitrypsin [4]. None of the 2 male patients reported with IGM showed any sign of systemic or autoimmune disease. 
The imaging findings of IGM have a wide spectrum. On mammography, ill-defined densities with no district margins are usually seen. Similarly, discrete, heterogeneous hypo- or hyperechoic masses with parenchymal distortion are described in ultrasound [16].

It is not unusual for localized granulomatosis to mimic carcinoma or breast abscess. Radiologic investigations, including breast ultrasound or mammograms, are rarely conclusive for differentiating malignant from benign lesions.

Since the awareness of breast cancer and other breast pathologies is lower in males than in females and the features overlap with malignancy, surgical excision of similar lesions is recommended.

\section{Conclusion}

Our case is only the second to demonstrate GM affecting male breast tissue. IGM is extremely rare in males and mimics breast cancer. Radiologic investigation may not be helpful to exclude malignancy. Therefore, surgical excision is recommended.

\section{Statement of Ethics}

This material has not been published in whole or in part elsewhere. All authors have been personally and actively involved in substantive work leading to the manuscript, and will hold themselves jointly and individually responsible for its content.

\section{Disclosure Statement}

The authors declare that no financial or other conflict of interest exists in relation to the content of this paper.

\section{References}

1 Sencha AN (ed): Imaging of Male Breast Cancer. Springer, 2015, pp 17-23.

-2 Kiyak G, Dumlu EG, Kilinc I, Tokaç M, Akbaba S, Gurer A, Ozkardes AB, Kilic M: Management of idiopathic granulomatous mastitis: dilemmas in diagnosis and treatment. BMC Surg 2014;14:66.

-3 Kumanov P, Deepinder F, Robeva R, Tomova A, Li J: Agarwal A: Relationship of adolescent gynecomastia with varicocele and somatometric parameters: a cross-sectional study in 6,200 healthy boys. J Adolesc Health 2007;41:126-131.

4 Kessler E, Wolloch Y: Granulomatous mastitis: a lesion clinically simulating carcinoma. Am J Clin Pathol 1972;58:642-646.

5 Barros M, Correia P, Sá L, Pereira da Silva D: Idiopathic granulomatous mastitis: a case report of breast abscess and review of literature. Acta Obstet Ginecol Port 2015;9:87-90.

-6 Reddy KM, Meyer CER, Nakdjevani A, Shrotria S: Idiopathic granulomatous mastitis in the male breast. Breast J 20015;11:73.

7 Turgut Erdemir A, Salih Gürel M, Kiremitçi Ü, Yavuz E, Kiroglu K: Idiopathic granulomatous mastitis: a case report. İstanbul Tip Dergisi 2007;1:42-44.

$>8$ Su F-H, Liu S-C, Suen J-H, Chen D-S, Sister Lou MA: Idiopathic granulomatous mastitis. Chang Gung Med J 2005;28:431-435.

-9 Binelli C, Lorimier G, Bertrand G, Parvery F, Bertrand AF, Verriele V: Granulomatous mastitis and Corynebacteria infection. Two case reports. J Gynecol Obstet Biol Reprod 1996;25:27-32. 


\section{Case Reports in Oncology}

\begin{tabular}{l|l}
\hline Case Rep Oncol 2016;9:516-519 \\
\hline DOI: 10.1159/000448990 & $\begin{array}{l}\text { C 2016 The Author(s). Published by S. Karger AG, Basel } \\
\text { www.karger.com/cro }\end{array}$ \\
\hline
\end{tabular}

Al Manasra and Al-Hurani: Granulomatous Mastitis: A Rare Cause of Male Breast Lump

10 Taylor GB, Paviour SD, Musaad S, Jones WO, Holland DJ: A clinicopathological review of 34 cases of inflammatory breast disease showing an association between Corynebacteria infection and granulomatous mastitis. Pathology 2003;35:109-119.

11 Veerysami M, Freeth M, Carmichael AR, Carmichael P: Wegener's granulomatosis of the breast. Breast J 2006;12:268-270.

12 Al-Khaffaf BH, Shanks JH, Bundred N: Erythema nodosum - an extramammary manifestation of granulomatous mastitis. Breast J 2006;12:569-570.

13 Salesi M, Karimifar M, Salimi F, Mahzouni P: A case of granulomatous mastitis with erythema nodosum and arthritis. Rheumatol Int 2011;31:1093-1095.

-14 Ozel L, Unal A, Unal E, Kara M, Erdoğdu E, Krand O, Güneș P, Karagül H, Demiral S, Titiz MI:

Granulomatous mastitis: is it an autoimmune disease? Diagnostic and therapeutic dilemmas. Surg Today 2012;42:729-733.

15 Hatwal D, Panda A, Suri V: Idiopathic Granulomatous Mastitis - Report of a Case with a Brief Review of Literature. J Clin Diagn Res 2010;4:2913-2917.

16 Ozturk M, Mavili E, Kahriman G, Akcan AC, Ozturk F: Granulomatous mastitis: radiological findings. Acta Radiol 2007;48:150-155.

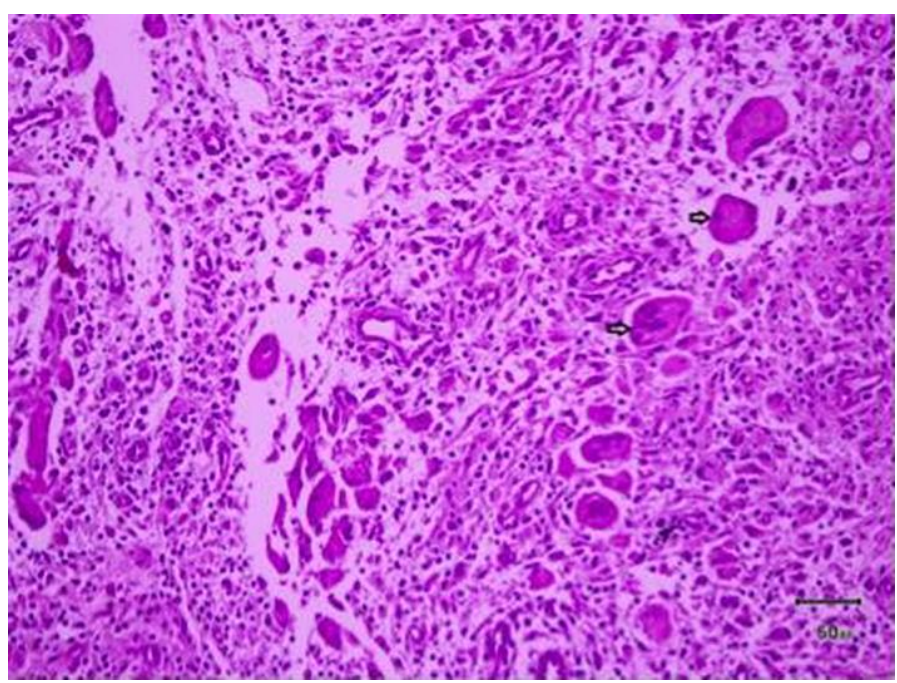

Fig. 1. Giant cells (tips of arrows) in a background of mastitis. 